CrossMark \& click for updates

Cite this: Org. Biomol. Chem., 2015, 13, 4931

\section{Elucidation of several neglected reactions in the GC-MS identification of sialic acids as heptafluorobutyrates calls for an urgent reassessment of previous claims $\uparrow$}

\begin{abstract}
Paola Rota, ${ }^{* a}$ Luigi Anastasia ${ }^{\mathrm{b}, \mathrm{c}}$ and Pietro Allevi ${ }^{\mathrm{a}}$
The current analytical protocol used for the GC-MS determination of free or 1,7-lactonized natural sialic acids (Sias), as heptafluorobutyrates, overlooks several transformations. Using authentic reference standards and by combining GC-MS and NMR analyses, flaws in the analytical protocol were pinpointed and elucidated, thus establishing the scope and limitations of the method. It was demonstrated that (a) Sias 1,7-lactones, even if present in biological samples, decompose under the acidic hydrolysis conditions used for their release; (b) Sias 1,7-lactones are unpredicted artifacts, accidentally generated from their parent acids; (c) the $\mathrm{N}$-acetyl group is quantitatively exchanged with that of the derivatizing perfluorinated anhydride; (d) the partial or complete failure of the Sias esterification-step with diazomethane leads to the incorrect quantification and structure attribution of all free Sias. While these findings prompt an urgent correction and improvement of the current analytical protocol, they could be instrumental for a critical revision of many incorrect claims reported in the literature.
\end{abstract}

Received 14th January 2015

Accepted 17th March 2015

DOI: 10.1039/c5ob00081e

www.rsc.org/obc

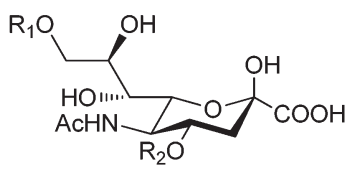

$$
\begin{aligned}
& \text { 1a Neu5Ac: } R_{1}=R_{2}=H \\
& \text { 1b: } R_{1}=A c ; R_{2}=H \\
& \text { 1c: } R_{1}=R_{2}=A c
\end{aligned}
$$

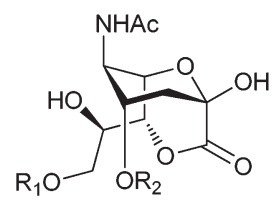

4a: $R_{1}=R_{2}=H$

4b: $R_{1}=A c ; R_{2}=H$

4c: $R_{1}=R_{2}=A c$

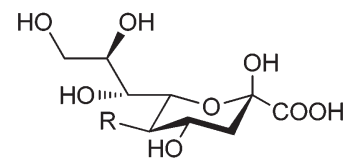

2 Neu5Gc: $\mathrm{R}=\mathrm{NHCOCH} \mathrm{H}_{2} \mathrm{OH}$ $3 \mathrm{KDN}: \mathrm{R}=\mathrm{OH}$

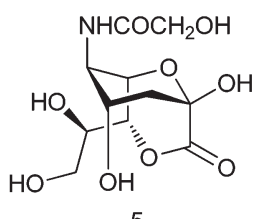

5 have been made to set-up suitable analytical methods for their identification in biological samples of different origin. ${ }^{1}$

The approach that more significantly contributed to identify and map the Sias family relies on the derivatization of their hydroxyls as heptafluorobutyrates (HFBs) before GC-MS analy-

\footnotetext{
${ }^{a}$ Department of Biomedical, Surgical and Dental Sciences, University of Milan, via Saldini 50, I-20133 Milan, Italy.E-mail: paola.rota@unimi.it; Fax: +390250316040; Tel: +390250316047

${ }^{b}$ Department of Biomedical Sciences for Health, University of Milan, Segrate Milan, Italy

${ }^{c}$ Laboratory of Stem Cells for Tissue Engineering, IRCCS Policlinico San Donato, San Donato, Milan, Italy

$\dagger$ Electronic supplementary information (ESI) available. See DOI: 10.1039/ c5ob00081e
} corresponding 1,7-lactones. about fifty different sialic acids, more than fifteen of which are new compounds, including the 1,7-lactones $4 \mathbf{a}-\mathbf{c}$ of Neu5Ac and the 1,7-lactone 5 of Neu5Gc as new members of the Sias family (Fig. 1). ${ }^{1,3 b, g, h}$ Owing to their stereochemistry, a surprising (yet unfortunately overlooked) feature of the allegedly newly identified natural 1,7-lactones was that they could only be linked to glycoconjugates with an unusual $\beta$-glycosidic
Fig. 1 Chemical structures of the most representative Sias and of the

sis. ${ }^{1 c, 3}$ For instance, the application of this method recognized 
bond. Nonetheless, this did not raise any concern, and several 1,7-lactones of Neu5Ac were identified in biological samples and reported to have crucial roles in a number of biological processes and pathologies. ${ }^{3 b, 3 i, 4}$ For instance, 4a has been described as a high-affinity ligand for interleukin $4,{ }^{4}$ and it was found overexpressed in various cancer cells ${ }^{3 i}$ and in polycythemia vera, a malignant disorder of hematopoietic stem cells. ${ }^{3 b}$

The crucial steps for the identification of these 1,7-lactones in glycoconjugates by GC-MS are acidic hydrolysis of their acetalic bonds, followed by a derivatization reaction with heptafluorobutyric anhydride (HFBAA), which is sometimes preceded by diazomethane treatment. ${ }^{1 c, 3 a, h}$ The initial step relies on the assumption that these 1,7-lactones are stable under acidic conditions. However, during our previous studies on Sias, ${ }^{5}$ we developed the synthesis of the free 1,7-lactones $4 \mathbf{a}$ and $5^{5 g-i}$ based on the ability of Neu5Ac 1a to form protected 1,7-lactones under acylation conditions, ${ }^{6}$ and observed their low stability in protic solvents. This unfavorable feature hindered their isolation and/or purification from aqueous reaction mixtures, ${ }^{5 g}$ and posed some initial doubts about the soundness of the analytical protocol currently used for their identification. ${ }^{1 c, 3}$ Moreover, once we synthesized $4 \mathbf{a}$ in the pure form and unequivocally assigned its structure by NMR, we subjected it to HFBAA derivatization. Surprisingly, we recorded different mass spectra from the one previously reported, ${ }^{1 c}$ which was obtained by subjecting a biological sample that supposedly contained the same lactone $\mathbf{4 a}$ to the hydrolysisderivatization analytical protocol. ${ }^{1 c, 3}$

Altogether this evidence started to support the notion that 1,7-lactones $4 \mathbf{a}-\mathbf{c}$ and other natural Sias could not be correctly identified with the current analytical methodology. ${ }^{1 c, 3}$ While this called for an extensive revision of the protocol, it also prompted for an urgent in-depth reexamination of the behavior of the 1,7-lactones $\mathbf{4 a - c}$, of their parent acids $\mathbf{1 a - c}$, and of other analogs under the same reaction conditions used for their identification. This step was mandatory in order to fix all the incorrect claims reported in the literature, ${ }^{1 c, 3}$ which were based on wrong structural assignments.

\section{Results and discussion}

Initially, we performed the synthesis of $4 a^{5 g-i}$ and of its new acetylated congeners $\mathbf{4 b}$, $\mathbf{c}$ by adapting and expanding our previous synthetic protocol, ${ }^{5 g-i}$ using the lactone $7 \mathbf{a}$ as a key intermediate as depicted in Scheme 1. In particular, we accomplished the synthesis of the acetylated 1,7-lactones $\mathbf{4 b}$-c by elaboration of the intermediate lactone $7 \mathbf{a}$, performing, in the final step, the reductive regeneration of its acetal group, under anhydrous conditions.

Then, we executed some hydrolytic stability tests on authentic samples of compounds $\mathbf{4 a}-\mathbf{c}$. Lactones $\mathbf{4 a}, \mathbf{b}^{5 f}$ were rather unstable in aqueous solution, as they completely decomposed within 24 hours at $23{ }^{\circ} \mathrm{C}$ by simply standing in $\mathrm{D}_{2} \mathrm{O}$, as revealed by NMR analyses. Only $4 \mathrm{c}$ survived for almost a week when dissolved in water at $23^{\circ} \mathrm{C}$.

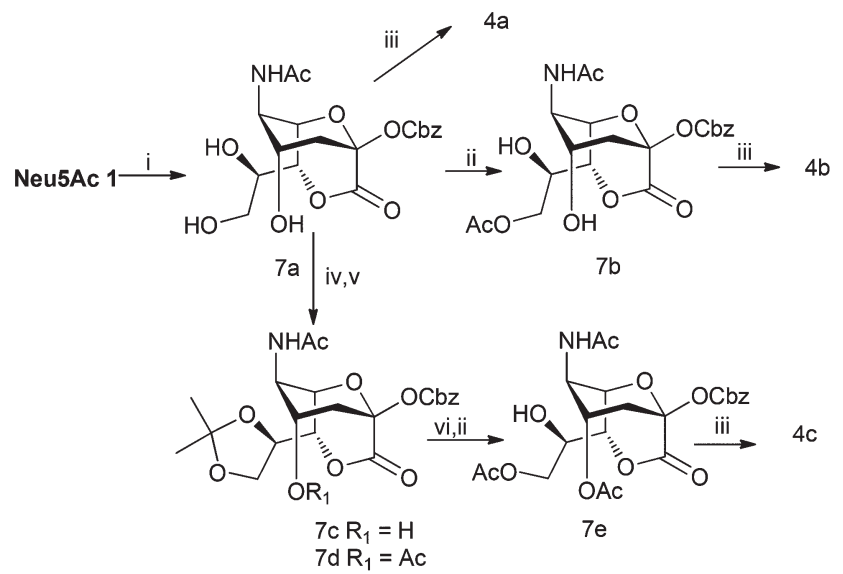

Scheme 1 Syntheses of lactones $4 a-c$. Reagents and conditions: (i) $\mathrm{CbzCl}, \mathrm{Et}_{3} \mathrm{~N}$, THF-DMF, $0{ }^{\circ} \mathrm{C} \rightarrow 23{ }^{\circ} \mathrm{C}, 30 \mathrm{~min}, 82 \%$; (ii) $(\mathrm{MeO})_{3} \mathrm{CMe}$, PPTS, THF, $23^{\circ} \mathrm{C}, 1 \mathrm{~h}$; (iii) $\mathrm{H}_{2}, \mathrm{Pd} / \mathrm{C}, \mathrm{AcOEt}, 25^{\circ} \mathrm{C}, 3 \mathrm{~h}$; (iv) $\mathrm{Me}_{2} \mathrm{C}(\mathrm{OMe})_{2}$, p-TSA, DMF, $23{ }^{\circ} \mathrm{C}, 1 \mathrm{~h}$; (v) $\mathrm{Ac}_{2} \mathrm{O}, \mathrm{Py}, \mathrm{DMAP}, 23^{\circ} \mathrm{C}, 1 \mathrm{~h}$; and (vi) moist $\mathrm{CF}_{3} \mathrm{COOH}, \mathrm{CH}_{2} \mathrm{Cl}_{2}, 40^{\circ} \mathrm{C}, 1 \mathrm{~h}$.

Moreover, as we anticipated, all of them decomposed under the hydrolytic treatment $(2 \mathrm{M}$ aqueous acetic acid solution, at $80{ }^{\circ} \mathrm{C}$ for $90 \mathrm{~min}$ ) used for their release from natural glycoconjugates. $^{1 c, 3 b, g, h}$ The decomposition was complete for $4 \mathbf{4 a}$ and 4b and partial, but relevant (35\%), for 4c. This evidence unambiguously reveals that Neu5Ac 1,7-lactones $\mathbf{4 a - c}$, even if present in biological samples of glycoconjugates, cannot properly survive to the acidic hydrolysis required for their release. Nonetheless, as they have been found by GC-MS in biological samples after acidic hydrolysis, we speculated that they could be unintentionally formed during the acylation of their parent acids 1a-c with HFBAA. If that was the case, based on our previous work on the $N$-transacylation of acetylamides, ${ }^{5 d, 5 e}$ the protected 1,7-lactones formed during the derivatization treatment with $\mathrm{HFBAA}$ (in $\mathrm{CH}_{3} \mathrm{CN}$ at $150^{\circ} \mathrm{C}$ for $5 \mathrm{~min}$ ), should have the structure of the $N$-transacylated congeners 8 a-c (Scheme 2).

We verified this hypothesis by observing the reaction of suitable amounts (15-30 mg scale) of the Sias 1a-c and of the corresponding lactones $\mathbf{4 a - c}$ with HFBAA. Remarkably, under the reported derivatization conditions, we obtained the same protected $N$-transacylated 1,7-lactones 8a-c (Scheme 2). This was evident from the GC-MS and NMR analyses of the crude reaction products that clearly demonstrated the lack of any acetamido group in the obtained compounds, which were in fact completely acylated. However, we were surprised to observe that their EI-MS fragmentation patterns (Fig. 2) were different from those reported for the alleged Neu5Ac 1,7lactones $\mathbf{4 a - c .}{ }^{1 c}$

In contrast, mass spectra were superimposable (for $\mathbf{8 a}, \mathbf{b}$ ) or very similar (for $\mathbf{8 c}$ ) to those reported for acids $\mathbf{1 a - c}$, which were analyzed as HFBs, after esterification with diazomethane, according to the protocol. ${ }^{1 c}$

In order to understand and clarify these discrepancies, we first excluded that the 1,7-lactones resulting from an inner 


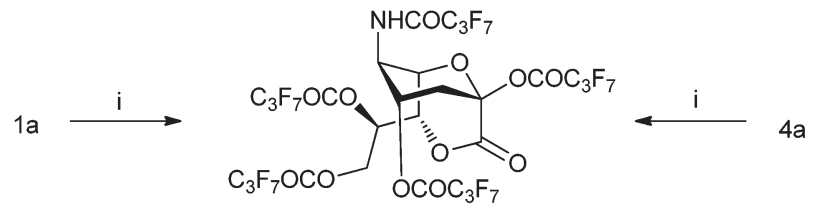

$8 a$

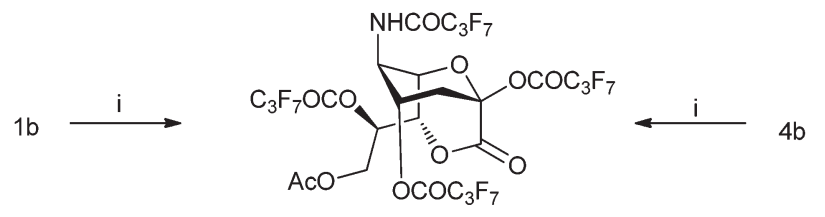

$8 b$

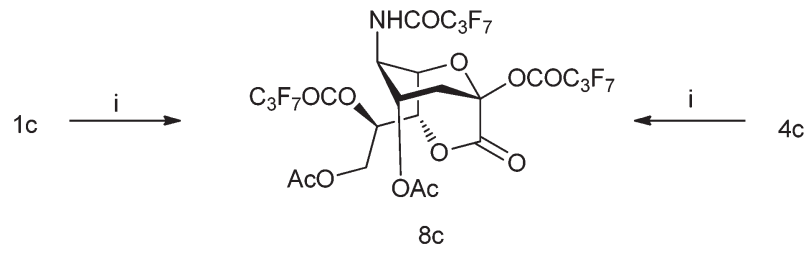

Scheme 2 Syntheses of heptafluorobutyric lactones 8a-c. Reagents and conditions: (i) $\mathrm{HFBAA}, \mathrm{MeCN}, 150^{\circ} \mathrm{C}, 5 \mathrm{~min}$.
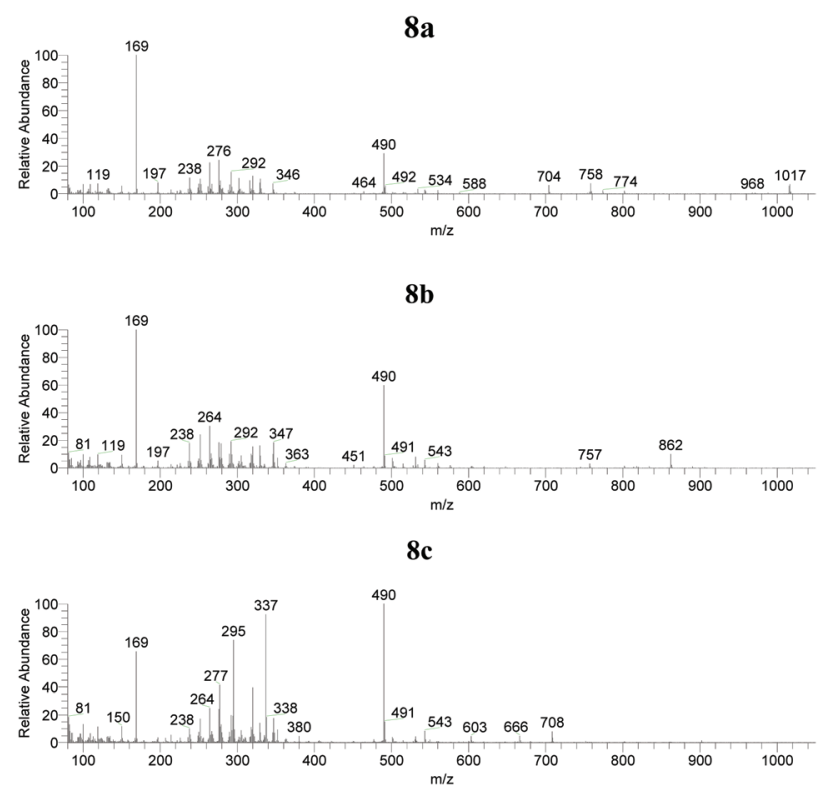

Fig. 2 El mass spectra of lactones $8 \mathrm{a}-\mathrm{c}$ obtained by derivatization (HFBAA, MeCN, $150^{\circ} \mathrm{C}, 5 \mathrm{~min}$ ) of the corresponding acids $1 \mathrm{a}-\mathrm{c}$ or of the lactones $4 \mathrm{a}-\mathrm{c}$ (see ESI†).

lactonization of the allegedly formed methyl esters. To this purpose, we subjected authentic and pure samples of Neu5Ac 1a-c methyl esters to the same GC-MS analysis as HFBs. However, none of the obtained products (or byproducts) showed an EI-MS profile similar to those we obtained for the authentic 1,7-lactones 4a-c (Fig. 3).

Based on our data, we considered highly plausible that the described $^{1 c, 3}$ esterification step with diazomethane was either
A

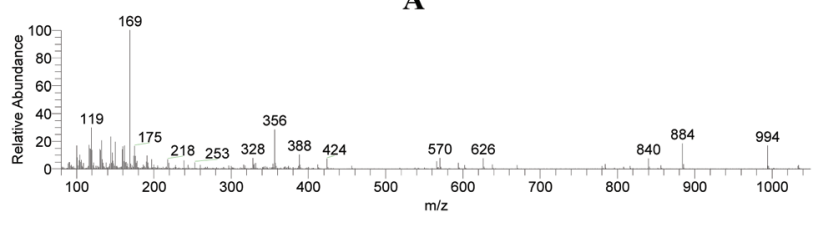

B

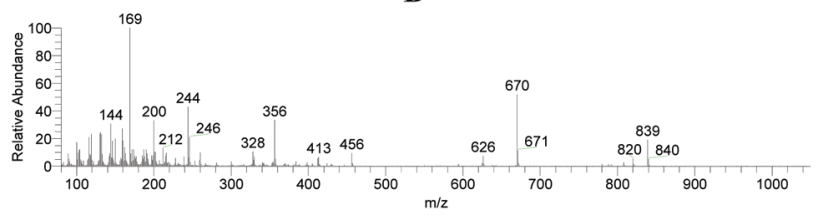

C
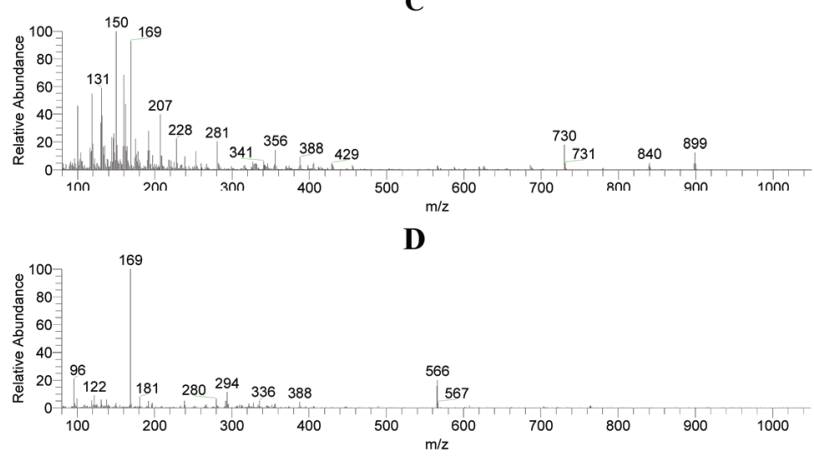

Fig. 3 El mass spectra obtained after derivatization (HFBAA, MeCN, $150{ }^{\circ} \mathrm{C}, 5 \mathrm{~min}$ ) of the methyl esters of sialic acids $1 \mathrm{a}-\mathrm{c}$. A and $\mathrm{B}$ represent the mass spectra of peaks at 7.80 and $8.84 \mathrm{~min}$ of the derivative of methyl ester of $1 \mathrm{a}$; $\mathrm{C}$ represent the mass spectrum of peak at $9.00 \mathrm{~min}$ of the derivative of methyl ester of $1 b$; $D$ represent the mass spectrum of peak at $8.51 \mathrm{~min}$ of the derivative of methyl ester of $1 \mathrm{c}$ (see ESI $\dagger$ ).

partially or totally unsuccessful, and that the unreacted Sias 1a-c underwent an unforeseen lactonization in the successive treatment with HFBAA. This forms the 1,7-lactones 8a-c, incorrectly identified in the reported experiments. ${ }^{1 c, 3}$ In fact, neglecting both the unsuccessful esterification with diazomethane and the successive transesterification with HFBAA, induced a massive misinterpretation of the GC-MS spectra, resulting in extensive errors also in the identification and quantification of free Sias present in the biological samples. ${ }^{1 c, 3}$

Finally, in order to complete this intricate puzzle, we had to establish the nature of the compounds responsible for the mass spectral fragmentations erroneously attributed to the 1,7lactones 4a-c HFBs. ${ }^{1 c, 3 b}$ A conceivable explanation appeared to be that they had the structure of untransacylated congeners of $\mathbf{8 a}-\mathbf{c}$, which are the unexpected byproducts of HFBAA treatment. In fact, according to the mechanism of the $N$-transacylation of normal amides, treatment of the Sias 1a-c (or of the lactones $\mathbf{4 a - c}$ ) with HFBAA should initially form the lactonic acetamides 9a-c (Scheme 3), which are in equilibrium with the corresponding imides $\mathbf{1 0 a - c}$ in the sealed reaction vessel. ${ }^{5 d}$

These imides, under the conditions described in the protocol (heating at $150{ }^{\circ} \mathrm{C}$ for $5 \mathrm{~min}$ ), should irreversibly form the 


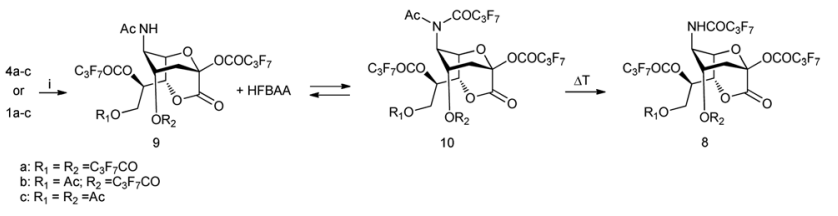

Scheme 3 Formation and $\mathrm{N}$-transacylation of lactones $8 \mathrm{a}-\mathrm{c}$. Reagents and conditions: (i) HFBAA excess, $\mathrm{MeCN}, 150{ }^{\circ} \mathrm{C}, 5 \mathrm{~min}$.
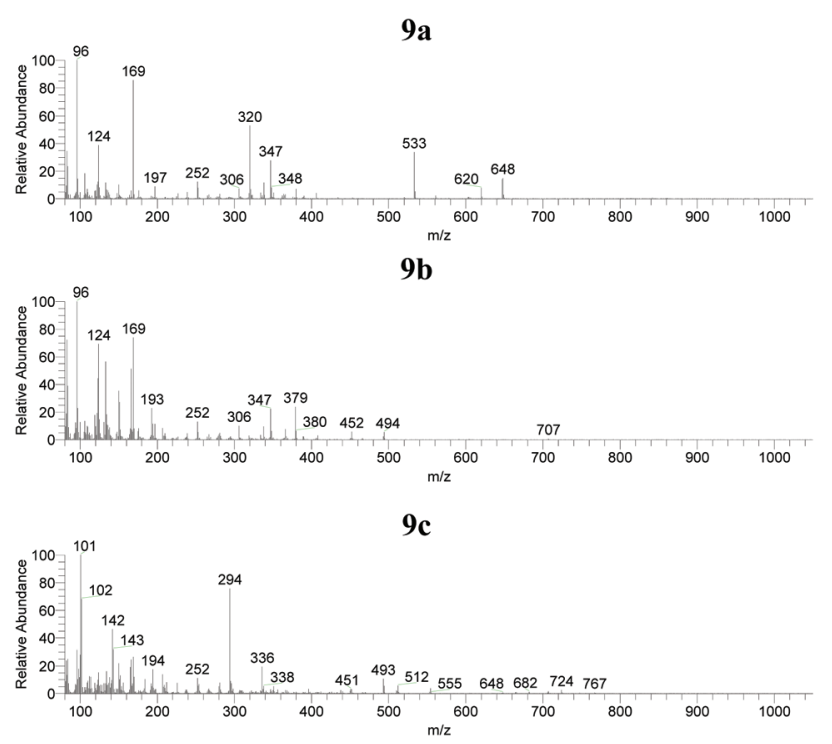

Fig. 4 El mass spectra of lactones $9 a-c$ obtained by derivatization with HFBAA at $23^{\circ} \mathrm{C}$ of the acids $1 \mathrm{a}-\mathrm{c}$ and of the lactones $4 \mathrm{a}-\mathrm{c}$ (see ESI $\dagger$ ).

$N$-transacylated amides $\mathbf{8 a - c}$, in nearly quantitative yields. In contrast, the imides 10a-c should at least partially survive when the reaction is performed at lower temperatures and/or for a shorter reaction time. During the work-up of the reaction mixtures (evaporation of the solvent and of the HFBAA excess), these imides should regenerate the untransacylated lactones 9a-c, in variable yields. If that was the case, variable amounts of the acetamides $\mathbf{9 a - c}$ should be present in the final reaction mixture, as a consequence of the equilibrium shift in favor of the HFBs 9a-c. To test this hypothesis, we treated Neu5Ac 1a-c and lactones $\mathbf{4 a - c}$ with HFBAA at lower temperature $\left(100-120{ }^{\circ} \mathrm{C}\right.$, for $\left.5 \mathrm{~min}\right) .{ }^{1 c}$ As we expected, GC-MS analyses of the reaction mixtures revealed that each $N$-transacylated lactone 8a-c was accompanied by a second minor compound showing a fragmentation pattern (Fig. 4) superimposable, or very similar, to that of the reported HFBs of the 1,7-lactone $4 a-c{ }^{1 c}$

The assignment of the correct structures, $\mathbf{9 a - c}$, to the obtained by-products, which were erroneously considered unesterified at the anomeric hydroxyl, was unequivocally confirmed by NMR analyses of authentic samples which were synthesized on a $15-30 \mathrm{mg}$ scale in reactions with HFBAA performed at $23^{\circ} \mathrm{C}$.

\section{Experimental}

\section{Materials and reagents}

All chemicals and solvents used were of analytical grade and purchased from Sigma-Aldrich (St. Louis, MO, USA). The sialic acid 1a and its methyl ester were from Sigma-Aldrich. The acetylated Sias $\mathbf{1 b}$ and $\mathbf{1} \mathbf{c}^{7}$ and the methyl ester of $\mathbf{1 b}^{8}$ were prepared according to the indicated literature reports. The methyl ester of acid $1 \mathrm{c}$ was obtained by treatment with diazomethane of the parent acid as a white solid glass showing: elemental analysis (Found: $\mathrm{C}, 47.2 ; \mathrm{H} 6.15 ; \mathrm{N} \mathrm{3.5;} \mathrm{C}_{16} \mathrm{H}_{25} \mathrm{NO}_{11}$ requires $\mathrm{C}, 47.2 ; \mathrm{H} 6.2 ; \mathrm{N} 3.4 \%) ; \delta_{\mathrm{H}}\left(\mathrm{CD}_{3} \mathrm{OD}\right) 5.31\left(1 \mathrm{H}, \mathrm{ddd}, J_{4,3 \mathrm{~b}} 11.3\right.$, $\left.J_{4,5} 10.1, J_{4,3 \mathrm{a}} 5.0,4-\mathrm{H}\right), 4.36\left(1 \mathrm{H}, \mathrm{dd}, J_{9 \mathrm{a}, 9 \mathrm{~b}} 11.6, J_{9 \mathrm{a}, 8} 2.4,9 \mathrm{a}-\mathrm{H}\right)$, $4.17\left(1 \mathrm{H}, \mathrm{dd}, J_{6,5} 10.6, J_{6,7} 1.2,1 \mathrm{H}, \mathrm{H}-6\right), 4.15-4.08$ (2H, overlapping, 9b-H- and 5-H), 3.89 (1H, ddd, $J_{8,7} 9.1, J_{8,9 \mathrm{~b}} 6.3, J_{8,9 \mathrm{a}} 2.4$, 8-H), $3.78\left(3 \mathrm{H}, \mathrm{s}, \mathrm{COOCH}_{3}\right), 3.50\left(1 \mathrm{H}, \mathrm{dd}, J_{7,8} 9.1, J_{7,6} 1.2,7-\mathrm{H}\right)$, $2.30\left(1 \mathrm{H}, \mathrm{dd}, J_{3 \mathrm{a}, 3 \mathrm{~b}} 12.7, J_{3 \mathrm{a}, 4} 5.0,3 \mathrm{a}-\mathrm{H}\right), 2.06\left(3 \mathrm{H}, \mathrm{s}, \mathrm{OCOCH}_{3}\right.$ at C-9), $2.02\left(3 \mathrm{H}, \mathrm{s}, \mathrm{OCOCH}_{3}\right.$ at C-4), 1.97-1.93 (4H, overlapping, $3 \mathrm{~b}-\mathrm{H}$ and $\left.\mathrm{NHCOCH}_{3}\right) ; \delta_{\mathrm{c}}\left(\mathrm{CD}_{3} \mathrm{OD}\right) 174.3,173.1,172.2,171.4$ (4C, $\mathrm{NHCOCH}_{3}, \mathrm{OCOCH}_{3}$ at C-4, $\mathrm{OCOCH}_{3}$ at C-9 and C-1), 96.5 (C-2), 71.7, 71.1, 70.2, 69.5 (C-4, C-6, C-7 and C-8), 67.8 (C-9), $53.3\left(\mathrm{COOCH}_{3}\right), 51.2(\mathrm{C}-5), 37.7(\mathrm{C}-3), 22.6\left(\mathrm{NHCOCH}_{3}\right), 20.9$ and $20.8\left(2 \mathrm{C}, \mathrm{OCOCH}_{3}\right.$ at $\mathrm{C}-4$ and $\mathrm{OCOCH}_{3}$ at C-9); MS (ESI positive) $m / z 430.4[\mathrm{M}+\mathrm{Na}]^{+}$.

The aqueous solutions of $2 \mathrm{M} \mathrm{CH}_{3} \mathrm{COOD}$ were taken from a stock solution prepared by the addition of $\left(\mathrm{CH}_{3} \mathrm{CO}\right)_{2} \mathrm{O}(945 \mu \mathrm{L}$, $10.0 \mathrm{mmol})$ to cold $\mathrm{D}_{2} \mathrm{O}(8.0 \mathrm{~mL})$ and dilution with $\mathrm{D}_{2} \mathrm{O}$ to $10.0 \mathrm{~mL}$.

\section{General remarks}

Nuclear magnetic resonance spectra were recorded at $303 \mathrm{~K}$ on a Bruker AM-500 spectrometer equipped with a $5 \mathrm{~mm}$ inversegeometry broadband probe and operating at $500.13 \mathrm{MHz}$ for ${ }^{1} \mathrm{H}$ and $125.76 \mathrm{MHz}$ for ${ }^{13} \mathrm{C}$. Chemical shifts are reported in parts per million (ppm, $\delta$ units) and are referenced for ${ }^{1} \mathrm{H}$ spectra, to a solvent residue proton signal $(\delta 7.26,3.31,2.50$ and $1.94 \mathrm{ppm}$, respectively for $\mathrm{CDCl}_{3}, \mathrm{CD}_{3} \mathrm{OD},\left(\mathrm{CD}_{3}\right)_{3} \mathrm{SO}$ and $\mathrm{CD}_{3} \mathrm{CN}$ solutions) and for ${ }^{13} \mathrm{C}$ spectra, to a solvent carbon signal (central line at $\delta 77.0,49.05,39.43$ and $1.24 \mathrm{ppm}$, respectively for $\mathrm{CDCl}_{3}, \mathrm{CD}_{3} \mathrm{OD},\left(\mathrm{CD}_{3}\right)_{3} \mathrm{SO}$ and $\mathrm{CD}_{3} \mathrm{CN}$ solutions). The ${ }^{1} \mathrm{H}$ and ${ }^{13} \mathrm{C}$ resonances were assigned by ${ }^{1} \mathrm{H}-{ }^{1} \mathrm{H}$ (COSY) and ${ }^{1} \mathrm{H}^{13}{ }^{13} \mathrm{C}$ (HSQC and HMBC) correlation 2D experiments. ${ }^{1} \mathrm{H}$ NMR data are tabulated in the following order: number of protons, multiplicity (s, singlet; d, doublet; br s, broad singlet; $\mathrm{m}$, multiplet), coupling constant(s) in hertz, assignment of proton(s). GC-MS analysis was performed by Finnigan TraceGC-ultra chromatograph coupled with a Finnigan Trace DSQ mass spectrometer (Thermo Scientific, Waltham, MA, USA). A capillary column $(25 \mathrm{~m} \times 0.25 \mathrm{~mm}$ i.d. $)$ with a HP-5MS bonded stationary phase film $(0.25 \mu \mathrm{m}$ thickness, Agilent Technologies, USA) was used. The inlet temperature was maintained at $260{ }^{\circ} \mathrm{C}$. The column oven was held at $100{ }^{\circ} \mathrm{C}$ for $1 \mathrm{~min}$ and then programmed from 100 to $270{ }^{\circ} \mathrm{C}$ at $20^{\circ} \mathrm{C} \mathrm{min}^{-1}$. The MS transfer line was set to $250^{\circ} \mathrm{C}$. Helium at a constant flow-rate of $1 \mathrm{~mL} \mathrm{~min}{ }^{-1}$ was used as a carrier gas. The injection mode was split (split ratio, 50:1; split flow, 
$50 \mathrm{~mL} \min ^{-1}$ ) and the injection volume was $1 \mu \mathrm{L}$. The analyses were performed in the EI mode (ionization energy $70 \mathrm{eV}$; source temperature $200{ }^{\circ} \mathrm{C}$ ). Optical rotations were performed on a polarimeter equipped with a $1 \mathrm{dm}$ tube; $[\alpha]_{\mathrm{D}}$ values are given in $10^{-1} \mathrm{deg} \mathrm{cm}^{2} \mathrm{~g}^{-1}$ and the concentrations are given in $\mathrm{g}$ per $100 \mathrm{~mL}$. ESI mass spectra were recorded using a Finnigan LCQ $_{\text {deca }}$ quadrupole ion trap mass spectrometer (Finningan Thermo Quest, San Jose, CA, USA) equipped with an electrospray ion (ESI) source and the spectra were collected in continuous flow mode by connecting the infusion pump directly to the ESI source. The reactions were monitored, when possible, by thin-layer chromatography (TLC) carried out on $0.25 \mathrm{~mm}$ E. Merck silica gel plates (60 F254) using UV light, $50 \%$ sulphuric acid or $0.2 \%$ ninhydrin in ethanol and heat as the developing agent. E. Merck 230-400 mesh silica gel was used for flash column chromatography.

\section{Preparation of 2-benzyloxycarbonyl- $\mathrm{N}$-acetylneuraminic acid 1,7-lactone $7 a$}

Sialic acid 1a (900 mg, $2.91 \mathrm{mmol})$, dissolved in DMF (10 mL) at $60{ }^{\circ} \mathrm{C}$, under stirring, was cooled at $0{ }^{\circ} \mathrm{C}$ and diluted with THF (8 mL). Then CbzCl (1.04 mL; $7.28 \mathrm{mmol}, 2.5$ eq.) in THF (4 mL) was added in a single portion, followed by $\mathrm{Et}_{3} \mathrm{~N}$ (1.20 $\mathrm{mL} ; 8.73 \mathrm{mmol}$, in a single addition). The mixture was then stirred for $30 \mathrm{~min}$ at $23^{\circ} \mathrm{C}$. After this, methanol $(2 \mathrm{~mL})$ was added dropwise and the stirring was continued for $15 \mathrm{~min}$. Evaporation of the solvent under reduced pressure (22 $\mathrm{mmHg}$ and then at $10^{-1} \mathrm{mmHg}$ ) afforded a crude residue, which, after purification by flash chromatography (eluting with AcOEt-MeOH, 9:1, v:v), afforded the pure Neu5Ac 1,7lactone 6 (1.01 g; 82\%) as a white solid: mp 122-124 ${ }^{\circ} \mathrm{C}$. The other physico-chemical properties are identical to those reported. This procedure uses a reduced amount of benzyloxycarbonyl chloride $(\mathrm{CbzCl})$ in the synthesis of the 1,7-lactones to address issues relating to the required excess of $\mathrm{CbzCl}^{5 i}$

\section{Preparation of 9-O-acetyl- $\mathrm{N}$-acetylneuraminic acid 1,7- lactone $4 \mathrm{~b}$}

Synthesis of 9-O-acetyl-2-benzyloxycarbonyl- $\mathrm{N}$-acetylneuraminic acid 1,7-lactone (7b). Trimethyl orthoacetate $(110 \mu \mathrm{L})$ and pyridinium $p$-toluenesulfonate $(10 \mathrm{mg})$ were added in a sequence to a solution of the 2-benzyloxycarbonyl 1,7-lactone 7a $(200 \mathrm{mg}, 0.480 \mathrm{mmol})$ dissolved in tetrahydrofuran $(5 \mathrm{~mL})$ and the solution was stirred at $25{ }^{\circ} \mathrm{C}$ for $1 \mathrm{~h}$. Then water $(0.2 \mathrm{~mL})$ was added and the solution stirred for $30 \mathrm{~min}$ before neutralization with a weak basic resin (IRA-67), filtered and the solvent evaporated under reduced pressure to afford a crude residue. The residue was purified by column chromatography on silica gel (eluting with AcOEt-MeOH, $95: 5$, v/v), to afford the pure 9-O-acetyl-2-benzyloxycarbonyl- $\mathrm{N}$-acetylneuraminic acid 1,7-lactone $7 \mathbf{b}(182 \mathrm{mg}, 85 \%)$ as a glass: $[\alpha]_{\mathrm{D}}^{20}+13.1$ (c 1 in $\mathrm{MeOH}$ ); elemental analysis (Found: C, 53.9; H, 5.4; N, $2.95 ; \mathrm{C}_{21} \mathrm{H}_{25} \mathrm{NO}_{11}$ requires $\left.\mathrm{C}, 54.0 ; \mathrm{H}, 5.4 ; \mathrm{N}, 3.0 \%\right) ; \delta_{\mathrm{H}}$ ( $\mathrm{CD}_{3} \mathrm{OD}$ ) 7.43-7.40 (5H, overlapping, $\mathrm{Ph}$ ), 5.24-5.16 (2H, AB system, $\left.\mathrm{CH}_{2} \mathrm{Ph}\right), 4.63\left(1 \mathrm{H}\right.$, br s, 6-H), $4.46\left(1 \mathrm{H}, \mathrm{d}, J_{7,8} 9.1,7-\mathrm{H}\right)$, 4.41 (dd, $\left.J_{9 \mathrm{a}, 9 \mathrm{~b}} 11.6, J_{9 \mathrm{a}, 8} 1.7,1 \mathrm{H}, 9 \mathrm{a}-\mathrm{H}\right), 4.24$ (1H, dd, $J_{9 \mathrm{~b}, 9 \mathrm{a}}$
11.6, $\left.J_{9 \mathrm{~b}, 8} 4.7,9 \mathrm{~b}-\mathrm{H}\right), 4.19-4.14$ (1H, 1H, 8-H), 4.12-4.09 (1H, br s, 4-H), 4.65-4.35 (1H, br s, H-5), $2.29\left(1 \mathrm{H}, \mathrm{dd}, J_{3 \mathrm{a}, 3 \mathrm{~b}} 13.9, J_{3 \mathrm{a}, 4}\right.$ 3.1, 3a-H), $2.11\left(1 \mathrm{H}\right.$, br d, $\left.J_{3 \mathrm{a}, 3 \mathrm{~b}} 13.9,3 \mathrm{~b}-\mathrm{H}\right), 2.11(3 \mathrm{H}, \mathrm{s}$, $\mathrm{OCOCH}_{3}$ at C-9), $2.01 \mathrm{ppm}\left(3 \mathrm{H}, \mathrm{s}, \mathrm{NHCOCH}_{3}\right) ; \delta_{\mathrm{c}}\left(\mathrm{CD}_{3} \mathrm{OD}\right)$ $172.9\left(2 \mathrm{C}, \mathrm{NHCOCH}_{3}\right.$ and $\mathrm{OCOCH}_{3}$ at C-9), 167.6 (C-1), 153.5 ( $\mathrm{PhCH}_{2} \mathrm{OCOO}$ ), 136.3, 129.8, 129.7, 129.4 (Ph), 94.9 (C-2), 80.0 (C-7), 73.2 (C-6), 71.4 ( $\left.\mathrm{PhCH}_{2} \mathrm{OCOO}\right), 69.6$ (C-8), 67.4 (C-4), 66.2 (C-9), 52.5 (C-5), 37.0 (C-3), $22.5\left(\mathrm{NHCOCH}_{3}\right), 20.8\left(\mathrm{OCOCH}_{3}\right.$ at C-9); MS (ESI positive) $m / z 490.1[\mathrm{M}+\mathrm{Na}]^{+}$.

Synthesis of 9-O-acetyl- $\mathrm{N}$-acetylneuraminic acid 1,7-lactone (4b). The 1,7-lactone $7 \mathbf{b}(300 \mathrm{mg}, 0.64 \mathrm{mmol})$ was dissolved in ethyl acetate $(65 \mathrm{~mL})$ and hydrogenated in the presence of $10 \%$ $\mathrm{Pd} / \mathrm{C}(30 \mathrm{mg}$ ) for $3 \mathrm{~h}$. Then the catalyst was filtered on a pad of Celite and washed with anhydrous THF. The removal of the solvent, under reduced pressure, afforded the 9-O-acetyl- $\mathrm{N}$ acetylneuraminic acid 1,7-lactone $4 \mathbf{b}(200 \mathrm{mg}, 95 \%)$ as an amorphous white solid that completely decomposes on standing at room temperature for one month and shows: $[\alpha]_{\mathrm{D}}^{20}+13.1$ (c 1 in THF); elemental analysis (Found: C, 46.8; H, 5.8; N, 4.1; $\mathrm{C}_{13} \mathrm{H}_{19} \mathrm{NO}_{9}$ requires $\left.\mathrm{C}, 46.85 ; \mathrm{H}, 5.75 ; \mathrm{N}, 4.2 \%\right) ; \delta_{\mathrm{H}}\left(\mathrm{DMSO}-d_{6}\right)$ : $8.24\left(1 \mathrm{H}, \mathrm{d}, J_{\mathrm{NH}, 5} 7.9, \mathrm{NHCOCH}_{3}\right), 7.35(1 \mathrm{H}, \mathrm{s}, \mathrm{OH}$ at C-2), 5.63 $\left(1 \mathrm{H}, \mathrm{d}, \mathrm{J}_{\mathrm{OH}, 8} 6.6, \mathrm{OH}\right.$ at C-8), $5.47\left(1 \mathrm{H}, \mathrm{d}, \mathrm{J}_{\mathrm{OH}, 4} 2.3\right.$, OH at C-4), 4.35-4.27 (2H, overlapping, 6- $\mathrm{H}$ and $9 \mathrm{a}-\mathrm{H}), 4.20\left(1 \mathrm{H}, \mathrm{d}, J_{7,8}\right.$ $8.9 \mathrm{~Hz}, 7-\mathrm{H}), 3.95$ (1H, dd, $\left.J_{9 \mathrm{~b}, 9 \mathrm{a}} 11.6, J_{9 \mathrm{~b}, 8} 5.9,9 \mathrm{~b}-\mathrm{H}\right), 3.81(1 \mathrm{H}$, br s, 4-H), 3.80-3.72 (2H, overlapping, 8- $\mathrm{H}$ and 5- $\mathrm{H}), 2.04(3 \mathrm{H}$, s, OCOCH $\left.H_{3}\right), 1.97\left(1 \mathrm{H}, \mathrm{dd}, J_{3 \mathrm{a}, 3 \mathrm{~b}} 13.8, J_{3 \mathrm{a}, 4} 2.9,3 \mathrm{a}-\mathrm{H}\right), 1.87(3 \mathrm{H}$, $\left.\mathrm{s}, \mathrm{NHCOCH}_{3}\right), 1.81\left(1 \mathrm{H}\right.$, br d, $\left.J_{3 \mathrm{~b}, 3 \mathrm{a}} 13.8,3 \mathrm{~b}-\mathrm{H}\right) ; \delta_{\mathrm{c}}\left(\mathrm{DMSO}-d_{6}\right)$ $170.3\left(1 \mathrm{C}, \mathrm{OCOCH}_{3}\right), 169.0(\mathrm{C}-1), 168.9\left(\mathrm{NHCOCH}_{3}\right), 90.4(\mathrm{C}-2)$, 77.7 (C-7), 70.1 (C-8), 68.4 (C-6), 65.9 (C-4), 64.8 (C-9), 50.2 (C-5), $30.3(\mathrm{C}-3), 22.3\left(\mathrm{NHCOCH}_{3}\right), 20.7\left(\mathrm{OCOCH}_{3}\right) ; \mathrm{MS}$ (ESI negative) $m / z 332.6[\mathrm{M}-\mathrm{H}]^{-}$.

\section{Preparation of 4,9-O-diacetyl- $\mathrm{N}$-acetylneuraminic acid 1,7-lactone 4c}

Synthesis of 8,9-isopropylidene-2-benzyloxycarbonyl- $N$-acetylneuraminic acid 1,7-lactone (7c). To a solution of 2-benzyloxycarbonyl $\mathrm{N}$-acetylneuraminic acid 1,7-lactone 7a $(200 \mathrm{mg}$, $0.480 \mathrm{mmol})$ in DMF $(2.0 \mathrm{~mL}), 2$,2-dimethoxypropane $(580 \mu \mathrm{L}$, $4.8 \mathrm{mmol}$ ) was added followed by $p$-toluenesulfonic acid ( $2 \mathrm{mg}$ ). The mixture was stirred at $23{ }^{\circ} \mathrm{C}$ for $1 \mathrm{~h}$ and then was neutralized with a weak basic resin (IRA-67) and filtered. The solvent was then evaporated, under reduced pressure, and the residue was chromatographed on silica gel (eluting with AcOEt-hexane, $95: 5, \mathrm{v} / \mathrm{v})$ to afford the 1,7-lactone 7c $(174 \mathrm{mg}$, $81 \%$ ) as a glass; $[\alpha]_{\mathrm{D}}^{20} 19.2(c 1$ in $\mathrm{MeOH})$; elemental analysis (Found: C, 56.8; H, 5.9; N, 3.1; $\mathrm{C}_{22} \mathrm{H}_{27} \mathrm{NO}_{10}$ requires $\mathrm{C}, 56.8 ; \mathrm{H}$, $5.85 ; \mathrm{N}, 3.0 \%) ; \delta_{\mathrm{H}}\left(\mathrm{CD}_{3} \mathrm{OD}\right) 7.40-7.32$ (5H, overlapping, $\mathrm{Ph}$ ), 5.20-5.15 (2H, AB system, $\left.\mathrm{CH}_{2} \mathrm{Ph}\right), 4.49$ (1H, br s, 6-H), 4.43 $\left(1 \mathrm{H}\right.$, ddd, $\left.J_{8,7} 9.4, J_{8,9 \mathrm{~b}} 5.7, J_{8,9 \mathrm{a}} 4.2,8-\mathrm{H}\right), 4.30\left(1 \mathrm{H}, \mathrm{d}, J_{7,8} 9.4\right.$, 7-H), 4.16-4.06 (3H, overlapping, 9a-H, 9b-H and 4-H), 4.01$3.99\left(1 \mathrm{H}\right.$, br s, 5-H), 2.27 (1H, dd, $\left.J_{3 \mathrm{a}, 3 \mathrm{~b}} 13.9, J_{3 \mathrm{a}, 4} 3.4,3 \mathrm{a}-\mathrm{H}\right)$, $2.11\left(1 \mathrm{H}, \mathrm{d}, J_{3 \mathrm{a}, 3 \mathrm{~b}} 13.9,3 \mathrm{a}-\mathrm{H}\right), 1.99\left(3 \mathrm{H}, \mathrm{s}, \mathrm{NHCOCH}_{3}\right), 1.40$ $\left(1 \mathrm{H}, \mathrm{s}, \mathrm{C}\left(\mathrm{CH}_{3}\right)_{2}\right), 1.34\left(1 \mathrm{H}, \mathrm{s}, \mathrm{C}\left(\mathrm{CH}_{3}\right)_{2}\right) ; \delta_{\mathrm{c}}\left(\mathrm{CD}_{3} \mathrm{OD}\right) 172.9(1 \mathrm{C}$, $\left.\mathrm{NHCOCH}_{3}\right), 167.5$ (C-1), $153.5\left(\mathrm{PhCH}_{2} \mathrm{OCOO}\right), 136.3,129.8$, 129.7, $129.4(\mathrm{Ph}), 111.2\left(1 \mathrm{C}, C\left(\mathrm{CH}_{3}\right)_{2}\right), 94.9(\mathrm{C}-2), 80.7(\mathrm{C}-7)$, 75.6 (C-6), 73.6 ( $\mathrm{PhCH}_{2} \mathrm{OCOO}$ ), 71.4 (C-8), 67.8 (C-4), 67.3 (C-9), 
52.4 (C-5), 37.0 (C-3), $27.4\left(1 \mathrm{C}, \mathrm{C}\left(\mathrm{CH}_{3}\right)_{2}\right), 25.5\left(1 \mathrm{C}, \mathrm{C}\left(\mathrm{CH}_{3}\right)_{2}\right)$, $22.4\left(\mathrm{NHCOCH}_{3}\right) ; \mathrm{MS}$ (ESI positive) $m / z 488.1[\mathrm{M}+\mathrm{Na}]^{+}$.

Synthesis of 8,9-isopropylidene-4-acetyl-2-benzyloxycarbonyl$\mathrm{N}$-acetylneuraminic acid 1,7-lactone (7d). Protected 1,7-lactone 7c $(240 \mathrm{mg}, 0.516 \mathrm{mmol})$, dissolved in pyridine $(0.6 \mathrm{~mL})$, was treated with acetic anhydride $(150 \mu \mathrm{L}, 1.50 \mathrm{mmol})$ containing a trace of 4-dimethylamino pyridine. After $1 \mathrm{~h}$ at $23{ }^{\circ} \mathrm{C}$, a methanol solution was added and concentrated under reduced pressure. Ice cold water was added to the crude residue and extracted with ethyl acetate. After drying with anhydrous sodium sulfate, the organic layer was filtered and the solvent evaporated under reduce pressure to afford a crude residue that was chromatographed on silica gel (eluting with AcOEthexane, $95: 5, \mathrm{v} / \mathrm{v})$ to afford the compound $7 \mathbf{d}(230 \mathrm{mg}, 87 \%)$ as a glass; $[\alpha]_{\mathrm{D}}^{20}+14.2$ ( c 1 in $\left.\mathrm{MeOH}\right)$; elemental analysis (Found: $\mathrm{C}, 56.7 ; \mathrm{H}, 5.8 ; \mathrm{N}, 2.7 ; \mathrm{C}_{24} \mathrm{H}_{29} \mathrm{NO}_{11}$ requires $\mathrm{C}, 56.8 ; \mathrm{H}$, 5.8; N, 2.8\%); $\delta_{\mathrm{H}}\left(\mathrm{CDCl}_{3}\right) 7.39-7.30$ (5H, overlapping, $\left.\mathrm{Ph}\right), 6.30$ $\left(1 \mathrm{H}, \mathrm{d}, J_{\mathrm{NH}, 5} 8.2, \mathrm{NHCOCH}_{3}\right), 5.20-5.14(2 \mathrm{H}, \mathrm{AB}$ system, $\left.\mathrm{CH}_{2} \mathrm{Ph}\right), 5.08(1 \mathrm{H}$, br s, $1 \mathrm{H}, 4-\mathrm{H}), 4.55(1 \mathrm{H}, \mathrm{s}, 6-\mathrm{H}), 4.51(1 \mathrm{H}$, ddd, $J_{8,7} 9.7, J_{8,9 \mathrm{~b}} 5.4, J_{8,9 \mathrm{a}} 4.0,8-\mathrm{H}$ ), 4.22-4.14 (4H, overlapping, 9a-H, 9b-H, 7-H and 5-H), $2.36\left(1 \mathrm{H}\right.$, br d, $J_{3 \mathrm{a}, 3 \mathrm{~b}} 14.9$, 3a-H), $2.16\left(1 \mathrm{H}, \mathrm{dd}, J_{3 \mathrm{a}, 3 \mathrm{~b}} 13.9, J_{3 \mathrm{~b}, 4} 3.7,3 \mathrm{a}-\mathrm{H}\right), 2.04(3 \mathrm{H}, \mathrm{s}$, $\mathrm{OCOCH}_{3}$ at C-4), 2.01 (3H, s, $\left.\mathrm{NHCOCH}_{3}\right), 1.42\left(1 \mathrm{H}, \mathrm{s}, \mathrm{C}\left(\mathrm{CH}_{3}\right)_{2}\right)$, $1.35\left(1 \mathrm{H}, \mathrm{s}, \mathrm{C}\left(\mathrm{CH}_{3}\right)_{2} ; \delta_{\mathrm{c}}\left(\mathrm{CD}_{3} \mathrm{OD}\right) 169.4\left(1 \mathrm{C}, \mathrm{OCOCH}_{3}\right.\right.$ at $\left.\mathrm{C}-4\right)$, 169.0 (1C, $\mathrm{NHCOCH}_{3}$ ), 164.4 (C-1), 151.7 ( $\left.\mathrm{PhCH}_{2} \mathrm{OCOO}\right), 134.0$, 128.9, 128.7, $128.3(\mathrm{Ph}), 110.2\left(1 \mathrm{C}, C\left(\mathrm{CH}_{3}\right)_{2}\right), 93.1(\mathrm{C}-2), 79.2$ (C-7), 73.6 (C-6), 72.3 ( $\left.\mathrm{PhCH}_{2} \mathrm{OCOO}\right), 70.7$ (C-8), 67.5 (C-4), 66.8 (C-9), 48.3 (C-5), 33.2 (C-3), $27.1 \mathrm{C}\left(\mathrm{CH}_{3}\right)_{2}, 25.0 \mathrm{C}\left(\mathrm{CH}_{3}\right)_{2}, 23.0$ $\left(\mathrm{NHCOCH}_{3}\right), 20.7\left(\mathrm{OCOCH}_{3}\right.$ at C-4); MS (ESI positive) $\mathrm{m} / z 530.4$ $[\mathrm{M}+\mathrm{Na}]^{+}$.

Synthesis of 4,9-diacetyl 2-benzyloxycarbonyl- $\mathrm{N}$-acetylneuraminic acid 1,7-lactone (7e). To a solution of 1,7-lactone 7d $(100 \mathrm{mg}, 0.200 \mathrm{mmol})$ in dichloromethane $(1.5 \mathrm{~mL})$ moist TFA $(0.4 \mu \mathrm{L})$ was added and the solution was refluxed for $1 \mathrm{~h}$. Then, a weak basic resin (IRA-67) was added to the mixture that was filtered and the solvent evaporated under reduced pressure to give a crude glass that was then purified by column chromatography on silica gel (eluting with AcOEt-hexane, from $95: 1$ then $90: 10, \mathrm{v} / \mathrm{v}$ ), to afford pure 4-O-acetyl-2-benzyloxycarbonyl- $N$-acetylneuraminic acid 1,7-lactone (87 $\mathrm{mg}, 85 \%$ ) as a glass; $[\alpha]_{\mathrm{D}}^{20}+17.2$ ( c 1 in $\left.\mathrm{MeOH}\right)$; elemental analysis (Found: C, 53.9; H, 5.3; N, 3.1; $\mathrm{C}_{21} \mathrm{H}_{25} \mathrm{NO}_{11}$ requires $\mathrm{C}, 54.0 ; \mathrm{H}$, $5.4 ; \mathrm{N}, 3.0 \%) ; \delta_{\mathrm{H}}\left(\mathrm{CD}_{3} \mathrm{OD}\right) 7.40-7.31$ (5H, overlapping, $\mathrm{Ph}$ ), 5.25-5.14 (2H, AB system, $\left.\mathrm{CH}_{2} \mathrm{Ph}\right), 5.06(1 \mathrm{H}$, br s, 4-H), $4.74(\mathrm{~s}$, $1 \mathrm{H} ; 6-\mathrm{H}), 4.51$ (1H, d, $\left.J_{7,8} 9.3,7-\mathrm{H}\right), 4.14-4.10(1 \mathrm{H}$, br m, 5-H), $4.04\left(1 \mathrm{H}\right.$, ddd, $\left.J_{8,7} 9.3, J_{8,9 \mathrm{~b}} 4.0, J_{8,9 \mathrm{a}} 2.9,8-\mathrm{H}\right), 3.86-3.75(2 \mathrm{H}$, overlapping, 9a-H and 9b-H), $2.40\left(1 \mathrm{H}, \mathrm{dd}, J_{3 \mathrm{a}, 3 \mathrm{~b}} 14.6, J_{3 \mathrm{a}, 4} 3.8\right.$, $1 \mathrm{H} ; 3 \mathrm{a}-\mathrm{H}), 2.28\left(1 \mathrm{H}, \mathrm{br} \mathrm{d}, J_{3 \mathrm{~b}, 3 \mathrm{a}} 14.6,1 \mathrm{H}, 3 \mathrm{~b}-\mathrm{H}\right), 2.05(3 \mathrm{H}, \mathrm{s}$, $\mathrm{OCOCH}_{3}$ at C-4), $2.03\left(3 \mathrm{H}, \mathrm{s}, \mathrm{NHCOCH}_{3}\right) ; \delta_{\mathrm{c}}\left(\mathrm{CD}_{3} \mathrm{OD}\right) 172.9$ (1C, $\mathrm{OCOCH}_{3}$ at C-4), 170.7 (1C, $\left.\mathrm{NHCOCH}_{3}\right), 167.3(\mathrm{C}-1), 153.5$ ( $\left.\mathrm{PhCH}_{2} \mathrm{OCOO}\right), 136.2,129.8,129.7,129.3(\mathrm{Ph}), 94.7$ (C-2), 80.0 (C-7), 73.4 (C-6), 71.6 ( $\left.\mathrm{PhCH}_{2} \mathrm{OCOO}\right), 71.5$ (C-8), 69.5 (C-4), 63.2 (C-9), 50.2 (C-5), 34.3 (C-3), $22.4\left(\mathrm{NHCOCH}_{3}\right), 20.7\left(\mathrm{OCOCH}_{3}\right.$ at C-4); MS (ESI positive) $m / z 490.5[\mathrm{M}+\mathrm{Na}]^{+}, 957.0[2 \mathrm{M}+\mathrm{Na}]^{+}$. The obtained 8,9-unprotected lactone $(80 \mathrm{mg}, 0.172 \mathrm{mmol})$ in THF $(2.0 \mathrm{~mL})$ was treated with trimethyl orthoacetate $(66 \mu \mathrm{L})$ containing a catalytic amount of pyridinium $p$-toluenesulfonate $(5 \mathrm{mg})$, for $1 \mathrm{~h}$ at $23{ }^{\circ} \mathrm{C}$. At this time, water $(0.2 \mathrm{~mL})$ was added, and the mixture stirred for $30 \mathrm{~min}$ at room temperature, and then neutralized with a weak basic resin (IRA-67), filtered and evaporated. The residue was chromatographed on silica gel (eluting with AcOEt-MeOH, from $98: 2$ to $95: 5, \mathrm{v} / \mathrm{v}$ ), to afford the title compound $7 \mathrm{e}(64 \mathrm{mg}, 77 \%)$ as a glass: $[\alpha]_{\mathrm{D}}^{20}+$ 14.1 ( $c 1$ in $\mathrm{MeOH}$ ); elemental analysis (Found: C, 54.14; $\mathrm{H}$, $5.4 ; \mathrm{N}, 2.7 ; \mathrm{C}_{23} \mathrm{H}_{27} \mathrm{NO}_{12}$ requires $\left.\mathrm{C}, 54.2 ; \mathrm{H}, 5.3 ; \mathrm{N}, 2.75 \%\right) ; \delta_{\mathrm{H}}$ ( $\mathrm{CD}_{3} \mathrm{OD}$ ) 7.40-7.31 (5H, overlapping, $\mathrm{Ph}$ ), 5.23-5.14 (2H, AB system, $\left.\mathrm{CH}_{2} \mathrm{Ph}\right), 5.07(1 \mathrm{H}$, br s, 4- $\mathrm{H}), 4.70(1 \mathrm{H}, \mathrm{s}, 6-\mathrm{H}), 4.48$ $\left(1 \mathrm{H}, \mathrm{d}, J_{7,8} 9.1,7-\mathrm{H}\right), 4.53-4.48(1 \mathrm{H}, \mathrm{m}, 8-\mathrm{H}), 4.29-4.19(2 \mathrm{H}$, overlapping, 9a-H and 9b-H), 4.21 (1H, br s, 5-H), 2.39 (1H, dd, $\left.J_{3 \mathrm{a}, 3 \mathrm{~b}} 14.7, J_{3 \mathrm{a}, 4} 3.8,3 \mathrm{a}-\mathrm{H}\right), 2.25\left(1 \mathrm{H}, \mathrm{br} \mathrm{d}, J_{3 \mathrm{a}, 3 \mathrm{~b}} 14.7,3 \mathrm{~b}-\mathrm{H}\right), 2.10$ $\left(3 \mathrm{H}, \mathrm{s}, \mathrm{OCOCH}_{3}\right.$ at C-9), $2.02\left(3 \mathrm{H}, \mathrm{s}, \mathrm{OCOCH}_{3}\right.$ at $\left.\mathrm{C}-4\right), 2.00(3 \mathrm{H}$, s, $\left.\mathrm{NHCOCH}_{3}\right) ; \delta_{\mathrm{c}}\left(\mathrm{CD}_{3} \mathrm{OD}\right): 172.9,172.8,170.6\left(3 \mathrm{C}, \mathrm{OCOCH}_{3}\right.$ at $\mathrm{C}-9, \mathrm{OCOCH}_{3}$ at $\mathrm{C}-4$ and $\left.\mathrm{NHCOCH}_{3}\right), 166.9$ (C-1), 153.4 ( $\left.\mathrm{PhCH}_{2} \mathrm{OCOO}\right), 136.1,129.8,129.7,129.4$ (Ph), 94.7 (C-2), 80.4 (C-7), 73.3 (C-6), 71.6 ( $\left.\mathrm{PhCH}_{2} \mathrm{OCOO}\right), 69.4$ (C-8), 69.2 (C-4), 66.2 (C-9), 50.0 (C-5), 34.2 (C-3), $22.4\left(\mathrm{NHCOCH}_{3}\right), 20.8$ and 20.7 (2C, $\mathrm{OCOCH}_{3}$ at $\mathrm{C}-4$ and $\mathrm{OCOCH}_{3}$ at C-9); MS (ESI positive) $\mathrm{m} / \mathrm{z}$ $532.3[\mathrm{M}+\mathrm{Na}]^{+}, 1041.8[2 \mathrm{M}+\mathrm{Na}]^{+}$.

Synthesis of 4,9-O-diacetylated $\mathrm{N}$-acetylneuraminic acid 1,7lactone (4c). The 2-protected 1,7-lactone 7e $(60 \mathrm{mg}$, $0.120 \mathrm{mmol}$ ) was dissolved in ethyl acetate $(13 \mathrm{~mL})$ and hydrogenated in the presence of $10 \% \mathrm{Pd} / \mathrm{C}(6 \mathrm{mg})$ for $3 \mathrm{~h}$. The catalyst was then filtered on a pad of Celite that was washed with anhydrous THF. The obtained solution was evaporated under reduced pressure to afford the title compound $4 \mathrm{c}$ (36 mg, 81\%) as an amorphous solid: $[\alpha]_{\mathrm{D}}^{20}+11.2$ ( $c 1$ in $\left.\mathrm{THF}\right)$; elemental analysis (Found: $\mathrm{C}, 48.1 ; \mathrm{H}, 5.6 ; \mathrm{N}, 3.8 ; \mathrm{C}_{15} \mathrm{H}_{21} \mathrm{NO}_{10}$ requires $\mathrm{C}$, $48.1 ; \mathrm{H}, 5.6 ; \mathrm{N}, 3.7 \%) ; \delta_{\mathrm{H}}\left(\mathrm{DMSO}-d_{6}\right) 8.44\left(1 \mathrm{H}, \mathrm{d}, J_{\mathrm{NH}, 5} 7.7,1 \mathrm{H}\right.$, $\left.\mathrm{NHCOCH}_{3}\right), 7.61\left(1 \mathrm{H}, \mathrm{s}, \mathrm{OH}\right.$ at C-2), $5.67\left(1 \mathrm{H}, \mathrm{d}, J_{\mathrm{OH}, 8}=6.3, \mathrm{OH}\right.$ at C-8), $4.85(1 \mathrm{H}$, br s, H-4), $4.41(1 \mathrm{H}, \mathrm{s}, 6-\mathrm{H}), 4.31(1 \mathrm{H}, \mathrm{dd}$, $\left.J_{9 \mathrm{a}, 9 \mathrm{~b}} 11.6, J_{9 \mathrm{a}, 8} 4.2,1 \mathrm{H}, 9 \mathrm{a}-\mathrm{H}\right), 4.28$ (1H, d, $\left.J_{7,8} 8.9, \mathrm{H}-7\right), 4.20$ $\left(1 \mathrm{H}, \mathrm{dd}, J_{9 \mathrm{~b}, 9 \mathrm{a}} 11.6, J_{8,9 \mathrm{a}} 6.1,9 \mathrm{a}-\mathrm{H}\right), 3.89-3.80$ (2H, overlapping, 8- $\mathrm{H}$ and 5-H), $2.15\left(1 \mathrm{H}, \mathrm{dd}, J_{3 \mathrm{a}, 3 \mathrm{~b}} 14.8, J_{3 \mathrm{~b}, 4} 3.7,3 \mathrm{a}-\mathrm{H}\right), 2.05$ $\left(3 \mathrm{H}, \mathrm{s}, \mathrm{OCOCH}_{3}\right), 1.94\left(3 \mathrm{H}, \mathrm{s}, \mathrm{OCOCH}_{3}\right), 1.89$ (4H, overlapping, $3 \mathrm{~b}-\mathrm{H}$ and $\left.\mathrm{NHCOCH}_{3}\right) ; \delta_{\mathrm{c}}\left(\mathrm{DMSO}-d_{6}\right) 170.3,169.1\left(2 \mathrm{C}, \mathrm{OCOCH}_{3}\right.$ at C-4 and $\mathrm{OCOCH}_{3}$ at C-9), $168.8(\mathrm{C}-1), 168.6\left(\mathrm{NHCOCH}_{3}\right)$, 90.4 (C-2), 78.2 (C-7), 70.1 (C-8), 68.5 (C-6), 68.2 (C-4), 65.0 (C-9), 47.7 (C-5), 30.3 (C-3), $22.3\left(\mathrm{NHCOCH}_{3}\right), 20.6,20.5$ (2C, $\mathrm{OCOCH}_{3}$ at C-4 and $\mathrm{OCOCH}_{3}$ at C-9); MS (ESI negative) $\mathrm{m} / \mathrm{z}$ $374.4[\mathrm{M}-\mathrm{H}]^{-}$.

\section{Stability tests of lactones $4 a-c$ under neutral and acidic conditions}

Tests under aqueous neutral conditions. General procedure. Each pure lactone $4 \mathbf{a}-\mathbf{c}(20 \mathrm{mg})$ was dissolved with $\mathrm{D}_{2} \mathrm{O}$ $(0.7 \mathrm{~mL})$ in a $\mathrm{NMR}$ tube at $23{ }^{\circ} \mathrm{C}$ and its proton spectrum was acquired at different times: immediately, after $15 \mathrm{~min}$, and after $24 \mathrm{~h}$.

The lactones $\mathbf{4 a}$ and $\mathbf{4 b}$ showed a very poor stability showing, also in the first acquired spectrum, the partial disappearance of the characteristic peaks observed for these lactones in $\left(\mathrm{CD}_{3}\right)_{2} \mathrm{SO}$. In all cases the starting lactone appears to 
be completely absent after $24 \mathrm{~h}$ without any documentable presence of the parent acids $\mathbf{1 a}$ and $\mathbf{1} \mathbf{b}$.

Lactone $4 \mathbf{c}$ showed greater stability in water, in fact its spectrum appeared unchanged after $24 \mathrm{~h}$ in $\mathrm{D}_{2} \mathrm{O}$.

Tests under aqueous acidic conditions ( $2 \mathrm{M}$ aq. acetic acid). General procedure. Each 1,7-lactone $4 \mathbf{a}-\mathbf{c}(20 \mathrm{mg})$ was dissolved at $23{ }^{\circ} \mathrm{C}$ in $\mathrm{CH}_{3} \mathrm{COOD}\left(2 \mathrm{M}\right.$ in $\left.\mathrm{D}_{2} \mathrm{O}\right)$ obtained by dissolving anhydrous $\mathrm{Ac}_{2} \mathrm{O}$ in $\mathrm{D}_{2} \mathrm{O}$ (see the Materials and reagents section) and the test tube was sealed. The solution was heated at $80{ }^{\circ} \mathrm{C}$ for $105 \mathrm{~min}$. At this time, each crude reaction mixture was subjected to the ${ }^{1} \mathrm{H}-\mathrm{NMR}$ analyses.

All signals corresponding to 1,7-lactones $\mathbf{4 a}$ and $\mathbf{4 b}$ completely disappeared. In the case of the lactone $\mathbf{4 a}$, some characteristic signals documented the presence of trace amounts of the parent sialic acid 1a in the reaction mixture. In contrast, no indication of the presence of the parent acid $\mathbf{1 b}$ could be obtained in the reaction of the lactone $\mathbf{4 b}$.

The 1,7-lactone 4c partially survived (around 65\%) the acidic hydrolysis and was accompanied by the parent acid 1c in the final reaction mixture.

\section{Synthesis and characterization of HFB derivatives 8a-c from the free parent acids $1 \mathrm{a}-\mathrm{c}$ and from the 1,7-lactones $4 \mathrm{a}-\mathrm{c}$}

General procedure. The appropriate acid or 1,7-lactone (0.05 mmol), dissolved in $\mathrm{CH}_{3} \mathrm{CN}(0.7 \mathrm{~mL})$, was treated with HFBAA $(245 \mu \mathrm{L}, 1.0 \mathrm{mmol})$ at $150{ }^{\circ} \mathrm{C}$ for $5 \mathrm{~min}$. An aliquot of the crude mixture was diluted with $\mathrm{CH}_{3} \mathrm{CN}$ and directly subjected to GC-MS analyses. Then, the remaining reaction mixture was evaporated under a stream of nitrogen and the crude residue was dissolved in $\mathrm{CDCl}_{3}$ for the NMR analyses.

Starting from acid 1a and from lactone 4a. The crude reaction mixtures obtained starting from the acid 1a and from the lactone 4a showed superimposable ${ }^{1} \mathrm{H}$ - and ${ }^{13} \mathrm{C}$-NMR spectra, identical to that of the compound of structure 8a reported in the literature ${ }^{5 f}$ and in GC-MS analysis, both showed a single peak with the same retention time $\left(t_{\mathrm{R}} 6.61 \mathrm{~min}\right)$ and mass spectrum (Fig. 2).

Starting from acid $\mathbf{1 b}$ and from lactone $4 \mathrm{~b}$. The crude residue obtained in the reactions of the acid $\mathbf{1 b}$ and of the lactone $\mathbf{4 b}$ showed superimposable ${ }^{1} \mathrm{H}-\mathrm{NMR}$ spectra, identical to that we reported ${ }^{5 f}$ for the compound of structure $\mathbf{8 b}$ and ${ }^{13} \mathrm{C}-\mathrm{NMR}$ spectrum $\delta_{\mathrm{c}}\left(\mathrm{CDCl}_{3}\right) 173.0\left(1 \mathrm{C}, \mathrm{OCOCH}_{3}\right.$ at C-9), 160.9 (C-1), 93.2 (C-2), 76.0 (C-7), 74.4 (C-8), 71.4 (C-6), 70.1 (C-4), 61.1 (C-9), 48.7 (C-5), 32.5 (C-3), 20.1 (1C, $\mathrm{OCOCH}_{3}$ at $\mathrm{C}-9)$. The GC-MS analyses of crude products obtained from compounds $\mathbf{1 b}$ and $\mathbf{4 b}$ showed, in both cases, a single peak with the same retention time $\left(t_{\mathrm{R}} 7.24 \mathrm{~min}\right)$ and identical mass spectrum (Fig. 2).

Starting from acid 1c and from lactone 4c. The crude residues obtained in the reaction of the acid $\mathbf{1 c}$ and the lactone $\mathbf{4 c}$ showed superimposable ${ }^{1} \mathrm{H}$ - and ${ }^{13} \mathrm{C}-\mathrm{NMR}$ spectra that were in agreement with the structure of the 1,7-lactone $8 \mathrm{c}: \delta_{\mathrm{H}}\left(\mathrm{CDCl}_{3}\right)$ : 7.36-7.30 (1H, m, $\left.\mathrm{NHCOCH}_{3}\right), 5.69-5.66(1 \mathrm{H}, \mathrm{m}, 8-\mathrm{H}), 5.51$ (1H, br s, 4-H), 4.95-4.88 (2H, overlapping, 7- $\mathrm{H}$ and $9 \mathrm{a}-\mathrm{H})$, 4.48-4.41 (3H, overlapping, 5- H, 6- $\mathrm{H}$ and 9b- $\mathrm{H}), 2.55(1 \mathrm{H}$, br d, $\left.J_{3 \mathrm{a}, 3 \mathrm{~b}} 14.6,3 \mathrm{a}-\mathrm{H}\right), 2.41\left(1 \mathrm{H}, \mathrm{dd}, J_{3 \mathrm{~b}, 3 \mathrm{a}} 14.6, J_{3 \mathrm{~b}, 4} 2.5,3 \mathrm{~b}-\mathrm{H}\right), 2.18$ $\left(3 \mathrm{H}, \mathrm{s}, \mathrm{OCOCH}_{3}\right.$ at $\left.\mathrm{C}-9\right), 2.13\left(3 \mathrm{H}, \mathrm{s}, \mathrm{OCOCH}_{3}\right.$ at $\left.\mathrm{C}-4\right) ; \delta_{\mathrm{c}}$ $\left(\mathrm{CDCl}_{3}\right) 172.8$ and $169.7\left(2 \mathrm{C}, \mathrm{OCOCH}_{3}\right.$ at $\mathrm{C}-4$ and $\mathrm{OCOCH}_{3}$ at C-9), 161.8 (C-1), 93.9 (C-2), 76.2 (C-7), 74.4 (C-8), 71.8 (C-6), 66.6 (C-4), 61.2 (C-9), 49.0 (C-5), 32.8 (C-3), 20.4 and 20.3 (2C, $\mathrm{OCOCH}_{3}$ at C-4 and $\mathrm{OCOCH}_{3}$ at C-9). Their GC-MS analysis showed in both cases a single peak with the same retention time ( $\left.t_{\mathrm{R}} 8.30 \mathrm{~min}\right)$ and mass spectrum (Fig. 2).

\section{Inspection by GC-MS analysis of analytical amount of acids 1a-c, lactones $4 a-c$ and methyl esters of acids 1a-c, after derivatization with HFBAA}

General procedure. The derivatization was performed adopting the protocol reported by Zanetta et $a l^{1 c, 3 b}$ avoiding the sometimes reported treatment with diazomethane. ${ }^{1 c, 3 b}$ In separate experiments, samples of the compounds (0.1-1 $\mu \mathrm{g})$ were dissolved in $\mathrm{CH}_{3} \mathrm{CN}(200 \mu \mathrm{L})$ with the addition of HFBAA $(25 \mu \mathrm{L})$. The vessels were then closed and heated at $150{ }^{\circ} \mathrm{C}$ for 5 min. After cooling, the solvent was stripped under a stream of nitrogen. The residue was then dissolved in anhydrous $\mathrm{CH}_{3} \mathrm{CN}$ and injected for GC-MS analysis.

Starting from Sias $1 \mathrm{a}-\mathbf{c}$ and their lactones $4 \mathrm{a}-\mathbf{c}$. The acids $\mathbf{1 a - c}$ and their 1,7-lactones $\mathbf{4 a - c}$ afforded chromatographic profiles and mass spectra identical to those described above for the 1,7-lactones $\mathbf{8 a - c .}$

Starting from methyl ester of sialic acid 1a. Authentic methyl ester of the acid $\mathbf{1 a}$ afforded a reaction product responsible for two chromatographic peaks (at $t_{\mathrm{R}} 7.80 \mathrm{~min}$ and $t_{\mathrm{R}}$ 8.84 min respectively) associated with mass spectral fragmentations (A and B, Fig. 3) that completely differ from that reported by Zanetta for sialic acid 1a, after methylation with diazomethane and perfluoracylation. ${ }^{1 c}$ They also differ from that of the lactone 8a that we obtained starting with the lactone $\mathbf{4 a}$ or with the acid $\mathbf{1 a}$.

Starting from methyl ester of sialic acid 1b. Authentic methyl ester of the acid $\mathbf{1 b}$ afforded a single chromatographic peak ( $\left.t_{\mathrm{R}} 9.00 \mathrm{~min}\right)$ associated with a mass spectrum (C, Fig. 3) completely different from that reported by Zanetta for the same acid, after methylation with diazomethane and perfluoracylation. ${ }^{3}$ It also differs from that we assigned to the lactone $\mathbf{8 b}$, starting from the lactone $\mathbf{4 b}$ or from the acid $\mathbf{1 b}$.

Starting from methyl ester of sialic acid 1c. Authentic methyl ester of the acid 1c afforded a single chromatographic peak ( $\left.t_{\mathrm{R}} 8.51 \mathrm{~min}\right)$ associated with a mass spectrum (D, Fig. 3) that completely differs from that attributed by Zanetta to acid 1c after methylation with diazomethane and perfluoracylation. ${ }^{1 c}$ It was also different from that we assigned to the lactone $\mathbf{8 c}$ obtained for the lactone $\mathbf{4 c}$ or from the acid $\mathbf{1 c}$.

\section{Preparation of the untransacylated derivatives $9 \mathrm{a}-\mathrm{c}$ by derivatization of the lactones $4 a-c$ and of the acids $1 \mathrm{a}-\mathrm{c}$}

General procedure. Each acid or 1,7-lactone (0.05 mmol) was dissolved in $\mathrm{CH}_{3} \mathrm{CN}(0.7 \mathrm{~mL})$ and treated with HFBAA $(245 \mu \mathrm{L} ; 1.0 \mathrm{mmol})$ at $23{ }^{\circ} \mathrm{C}$ for $3 \mathrm{~h}$. Then, each reaction mixture was evaporated under a stream of nitrogen and two samples of the crude residue were dissolved in $\mathrm{CDCl}_{3}$ for the NMR analyses, and in $\mathrm{CH}_{3} \mathrm{CN}$ for the GC-MS analyses. Parallel 
reactions of the lactones $4 \mathbf{4 a - c}$ and the acids $1 \mathbf{a}-\mathbf{c}$ were also performed at $120{ }^{\circ} \mathrm{C}$ for $5 \mathrm{~min}$. After the work-up, the crude reaction mixtures were subjected exclusively to GC-MS analyses.

Preparation of the lactone 9a. Derivatization treatment of the lactone $\mathbf{4 a}$ at $23{ }^{\circ} \mathrm{C}$ afforded the lactone $\mathbf{9 a}$, as a crude product that decomposes in any purification attempt. It showed: $\delta_{\mathrm{H}}\left(\mathrm{CDCl}_{3}\right) 6.60\left(1 \mathrm{H}, \mathrm{d}, J_{\mathrm{NH}, 5} 7.9, \mathrm{NH}\right), 5.68(1 \mathrm{H}$, ddd, $\left.J_{8,7} 8.3, J_{8,9 \mathrm{~b}} 3.8, J_{8,9 \mathrm{a}} 2.1,8-\mathrm{H}\right), 5.49(1 \mathrm{H}$, br s, $4-\mathrm{H}), 4.99(1 \mathrm{H}$, dd, $\left.J_{9 a, 9 b} 13.0, J_{9 a, 8} 2.1,9 \mathrm{a}-\mathrm{H}\right), 4.86\left(1 \mathrm{H}, \mathrm{d}, J_{8,7} 8.3,7-\mathrm{H}\right), 4.76$ $\left(1 \mathrm{H}, \mathrm{dd}, J_{9 \mathrm{~b}, 9 \mathrm{a}} 13.0, J_{9 \mathrm{~b}, 8} 3.8,9 \mathrm{~b}-\mathrm{H}\right), 4.51\left(1 \mathrm{H}, \mathrm{br} \mathrm{d}, J_{5, \mathrm{NH}} 7.9\right.$, $5-\mathrm{H}), 4.38(1 \mathrm{H}, \mathrm{br} \mathrm{s}, 6-\mathrm{H}), 2.59\left(1 \mathrm{H}, \mathrm{dd}, J_{3 \mathrm{a}, 3 \mathrm{~b}} 15.4, J_{3 \mathrm{~b}, 4} 2.0\right.$, 3a-H), 2.54 (1H, dd, J3b,3a 15.4, J3b,4 3.9, 3b-H) $2.19(3 \mathrm{H}, \mathrm{s}$, $\left.\mathrm{NHCOCH}_{3}\right) ; \delta_{\mathrm{c}}\left(\mathrm{CDCl}_{3}\right) 173.0\left(1 \mathrm{C}, \mathrm{NHCOCH}_{3}\right), 160.5(\mathrm{C}-1), 93.4$ (C-2), 75.2 (C-7), 73.2 (C-8), 72.1 (C-6), 70.4 (C-4), 63.5 (C-9), 48.1 (C-5), 32.5 (C-3, $22.5\left(\mathrm{NHCOCH}_{3}\right)$.

Its GC-MS analysis showed a single chromatographic peak $\left(t_{\mathrm{R}} 7.47 \mathrm{~min}\right)$ associated with the mass spectrum reported in the figure (Fig. 4). The EI spectrum of the lactone 9a was identical in all respects to that erroneously attributed by Zanetta et $a l .{ }^{1 c}$ to the congener unesterified at the anomeric hydroxyl.

Performing the derivatization of the lactone $4 \mathbf{a}$ and of the acid $1 \mathrm{a}$, at $120^{\circ}$ for $5 \mathrm{~min}$, we obtained, in both cases, a reaction product responsible for two peaks in GC-MS analysis. We identified the major compound as the lactone $\mathbf{8 a}$, and the minor one as the lactone $\mathbf{9 a}$.

Preparation of the lactone $9 \mathrm{~b}$. Derivatization treatment of lactone $\mathbf{4 b}$ afforded a product, identified as the crude lactone 9b, unstable to any attempted purification. It showed: $\delta_{\mathrm{H}}$ $\left(\mathrm{CDCl}_{3}\right) 7.04\left(\mathrm{~d}, J_{\mathrm{NH}, 5} 7.6 \mathrm{~Hz}, \mathrm{NH}\right), 5.58\left(1 \mathrm{H}, \mathrm{ddd}, J_{8,7} 6.6, J_{8,9 \mathrm{~b}}\right.$ $\left.5.9, J_{8,9 \mathrm{a}} 2.0,8-\mathrm{H}\right), 5.54(1 \mathrm{H}, \mathrm{br} \mathrm{s}, 4-\mathrm{H}), 4.99$ (1H, dd, $J_{9 \mathrm{a}, 9 \mathrm{~b}} 13.2$, $\left.J_{9 \mathrm{a}, 8} 2.0,9 \mathrm{a}-\mathrm{H}\right), 4.86\left(1 \mathrm{H}, \mathrm{d}, J_{8,7} 6.6, \mathrm{H}-7\right), 4.52-4.45(2 \mathrm{H}$, overlapping, 5- $\mathrm{H}$ and 6-H), 4.41 (1H, dd, $\left.J_{9 \mathrm{~b}, 9 \mathrm{a}} 13.2, J_{9 \mathrm{~b}, 8} 5.9,9 \mathrm{~b}-\mathrm{H}\right)$, 2.60-2.51 (2H, overlapping, 3a- $\mathrm{H}$ and $3 \mathrm{~b}-\mathrm{H}), 2.18(3 \mathrm{H}, \mathrm{s}$, $\mathrm{OCOCH}_{3}$ at C-9), $2.14\left(3 \mathrm{H}, \mathrm{s}, \mathrm{NHCOCH}_{3}\right) ; \delta_{\mathrm{c}}\left(\mathrm{CDCl}_{3}\right) 173.7$ (1C, $\mathrm{OCOCH}_{3}$ at C-9), 173.6 (1C, $\mathrm{NHCOCH}_{3}$ ), 161.4 (C-1), 93.3 (C-2), 76.2 (C-7), 75.0 (C-8), 71.8 (C-6), 70.6 (C-4), 61.5 (C-9), 48.3 (C-5), 32.3 (C-3), $22.2\left(\mathrm{NHCOCH}_{3}\right), 20.2\left(1 \mathrm{C}, \mathrm{OCOCH}_{3}\right.$ at C-9).

Its GC-MS analysis showed a single chromatographic peak $\left(t_{\mathrm{R}} 8.55 \mathrm{~min}\right)$ associated with the mass spectrum reported in the figure (Fig. 4). The mass spectrum of the lactone $\mathbf{9 b}$ was identical in all respects to that erroneously attributed by Zanetta et $a l .{ }^{1 c}$ to the congener unesterified at the anomeric hydroxyl.

Performing the derivatization of the lactone $\mathbf{4 b}$ and of the acid $\mathbf{1 b}$, at $120^{\circ}$ for $5 \mathrm{~min}$, we obtained, in both cases, a reaction product responsible for two peaks in GC-MS analysis. We identified the major compound as the lactone $\mathbf{8 b}$, and the minor one as the lactone $\mathbf{9 b}$.

Preparation of the lactone 9c. Derivatization treatment of lactone $\mathbf{4 c}$ afforded a product, identified as the lactone 9c, unstable to any attempted purification, showing: $\delta_{\mathrm{H}}\left(\mathrm{CDCl}_{3}\right)$ $6.92\left(1 \mathrm{H}, \mathrm{d}, J_{\mathrm{NH}, 5} 7.9, \mathrm{NH}\right), 5.62\left(1 \mathrm{H}, \mathrm{ddd}, J_{8,7} 8.5, J_{8,9 \mathrm{~b}} 6.3, J_{8,9 \mathrm{a}}\right.$ 2.2, 8-H), 5.30-5.26 (1H, br s, 4- $\mathrm{H}), 4.92-4.86$ (2H, overlapping, 7- $\mathrm{H}$ and 9a-H), 4.45 (1H, br s, 6-H), 4.42-4.36 (2H, overlapping, 5-H and 9b-H), 2.49 (1H, br d, $\left.J_{3 \mathrm{a}, 3 \mathrm{~b}} 15.0,3 \mathrm{a}-\mathrm{H}\right), 2.37$ (1H, dd,
$\left.J_{3 \mathrm{~b}, 3 \mathrm{a}} 15.0, J_{3 \mathrm{~b}, 4} 3.7,1 \mathrm{H}, 3 \mathrm{~b}-\mathrm{H}\right), 2.19\left(3 \mathrm{H}, \mathrm{s}, \mathrm{COCH}_{3}\right), 2.18(3 \mathrm{H}, \mathrm{s}$, $\left.\mathrm{COCH}_{3}\right), 2.12\left(3 \mathrm{H}, \mathrm{s}, \mathrm{NHCOCH}_{3}\right) ; \delta_{\mathrm{c}}\left(\mathrm{CDCl}_{3}\right) 173.4$ and 170.3 $\left(3 \mathrm{C}, \mathrm{OCOCH}_{3}\right.$ at C-4, $\mathrm{OCOCH}_{3}$ at C-9 and $\left.\mathrm{NHCOCH}_{3}\right), 162.3$ (C-1), 94.0 (C-2), 76.5 (C-7), 74.9 (C-8), 72.1 (C-6), 67.2 (C-4), 61.6 (C-9), 48.7 (C-5), 32.6 (C-3), $22.1\left(\mathrm{NHCOCH}_{3}\right), 20.4$ (2C, $\mathrm{COCH}_{3}$ at $\mathrm{C}-9$ and $\mathrm{COCH}_{3}$ at C-4).

Its GC-MS analysis showed a single chromatographic peak $\left(t_{\mathrm{R}} 9.74 \mathrm{~min}\right)$ associated with the mass spectrum reported in the figure (Fig. 4). The mass spectrum of the lactone 9c was identical in all respects to that erroneously attributed by Zanetta et $a l .{ }^{1 c}$ to the congener unesterified at the anomeric hydroxyl.

Performing the derivatization of the lactone $\mathbf{4 c}$ and of the acid 1c, at $120^{\circ}$ for $5 \mathrm{~min}$, we obtained, in both cases, a reaction product responsible for two peaks in GC-MS analysis. We identified the major component of the mixture as the lactone $\mathbf{8 c}$, and the minor one as the lactone $\mathbf{9 c}$.

\section{Conclusions}

This work demonstrates that the current analytical protocol ${ }^{1 c, 3}$ for the GC-MS identification of natural Sias and of their 1,7lactones as HFBs in glycoconjugates has numerous critical flaws. Unfortunately, neglecting several reactions encouraged the misinterpretation of many crucial MS spectra. This caused a detrimental domino effect, ${ }^{1 b}$ as many claims in the literature rely on the incorrect identification of Sias with this analytical method. ${ }^{1 c}$ For instance we established that 1,7-lactones 4a-c, although they had been identified with this methodology and reported to have important biological roles also in pathologies, ${ }^{3 b, 3 i, 4}$ could not be determined with this approach, because they are decomposed during the hydrolysis step. In fact, those detected 1,7-lactones are merely artifacts formed by lactonization of the corresponding acids, under the acylation conditions used for their derivatization. The acylation with HFBAA also causes a second neglected reaction which exchanges the $N$-acetyl group (present in all Sias of the Neu5Ac family) with that of the derivatizing perfluorurated anhydride, to afford different derivatives from those predicted and reported. Neglecting this transformation and overlooking the unexpected failure of the esterification step with diazomethane also caused extensive errors in the identification and quantification of free Sias. While we feel that an urgent correction and improvement of the present analytical protocol ${ }^{1 c, 3}$ is mandatory, we are assured that the extensive data herein reported will allow a critical revision of the literature in this field.

\section{Acknowledgements}

We gratefully acknowledge Prof. Mario Anastasia for the valuable suggestions and his unrelenting encouragement, and Ms Irene Delcarro for her skilled technical assistance. 


\section{Notes and references}

1 (a) X. Chen and A. Varki, ACS Chem. Biol., 2010, 5, 163-176; (b) T. Angata and A. Varki, Chem. Rev., 2002, 102, 439; (c) J. P. Zanetta, A. Pons, M. Iwersen, C. Mariller, Y. Leroy, P. Timmerman and R. Schauer, Glycobiology, 2001, 11, 663.

2 M. J. Kiefel and M. von Itzstein, Chem. Rev., 2002, 102, 471490.

3 (a) J. P. Zanetta, P. Timmerman and Y. Leroy, Glycobiology, 1999, 9, 255; (b) D. Bratosin, C. Palii, A. D. Moicean, J. P. Zanetta and J. Montreuil, Biochimie, 2007, 89, 355; (c) I. Popa, A. Pons, C. Mariller, T. Tai, J. P. Zanetta, L. Thomas and J. Portoukalian, Glycobiology, 2007, 17, 367373; (d) J. P. Zanetta, V. Srinivasan and R. Schauer, Biochimie, 2006, 88, 171-178; (e) A. Bohin, F. Bouchart, C. Richet, S. Kol, Y. Leroy, P. Timmerman, G. Huet, J. P. Bohin and J. P. Zanetta, Anal. Biochem., 2005, 340, 231; (f) J. P. Zanetta, A. Pons, C. Richet, G. Huet, P. Timmerman, Y. Leroy, A. Bohin, J. P. Bohm, P. A. Trinel, D. Poulain and J. Hofsteenge, Anal. Biochem., 2004, 329, 199; $(g)$ T. Bulai, D. Bratosin, A. Pons, J. Montreuil and J. P. Zanetta, FEBS Lett., 2003, 534, 185; (h) A. Pons, C. Richet, C. Robbe, A. Herrmann, P. Timmerman, G. Huet, Y. Leroy, I. Carlstedt, C. Capon and J. P. Zanetta, Biochemistry, 2003, 42, 8342; (i) I. Popa, J. P. Zanetta, J. Portoukalian and L. Thomas, J. Invest. Dermatol., 2002, 118, 903; (j) A. Rinninger, C. Richet, A. Pons, G. Kohla, R. Schauer, H. C. Bauer, J. P. Zanetta and R. Vlasak, Glycoconjugate J., 2006, 23, 73-84.

4 (a) C. Cebo, T. Dambrouck, E. Maes, C. Laden, G. Strecker, J. C. Michalski and J. P. Zanetta, J. Biol. Chem., 2001, 276,
5685; (b) C. Cebo, G. Vergoten and J. P. Zanetta, Biochim. Biophys. Acta, 2002, 1572, 422.

5 (a) P. Allevi, E. A. Femia, M. L. Costa, R. Cazzola and M. Anastasia, J. Chromatogr., A, 2008, 1212, 98; (b) P. Rota, I. S. Agnolin, P. Allevi and M. Anastasia, Eur. J. Org. Chem., 2012, 2508; (c) P. Rota, P. Allevi, I. S. Agnolin, R. Mattina, N. Papini and M. Anastasia, Org. Biomol. Chem., 2012, 10, 2885; (d) P. Rota, P. Allevi, R. Colombo, M. L. Costa and M. Anastasia, Angew. Chem., 2010, 122, 1894; P. Rota, P. Allevi, R. Colombo, M. L. Costa and M. Anastasia, Angew. Chem., Int. Ed., 2010, 49, 1850-1853; (e) P. Rota, P. Allevi, M. L. Costa and M. Anastasia, Tetrahedron: Asymmetry, 2010, 21, 2681; (f) P. Rota, P. Allevi, R. Mattina and M. Anastasia, Org. Biomol. Chem., 2010, 8, 3771; (g) P. Allevi, P. Rota, R. Scaringi, R. Colombo and M. Anastasia, J. Org. Chem., 2010, 75, 5542; (h) P. Allevi, M. Anastasia, M. L. Costa and P. Rota, Tetrahedron: Asymmetry, 2011, 22, 338; (i) R. Colombo, M. Anastasia, P. Rota and P. Allevi, Chem. Commun., 2008, 5517, DOI: 10.1039/ c5cc90091c.

6 (a) N. Sugiyama, K. Sugai, N. Yamada, M. Goto, C. Ban, K. Furuhata, H. Takayanagi and H. Ogura, Chem. Pharm. Bull., 1988, 36, 1147; (b) S. Sato, K. Furuhata and H. Ogura, Chem. Pharm. Bull., 1988, 36, 4678.

7 (a) H. Ogura, K. Furuhata, S. Sato, K. Anazawa, M. Itoh and Y. Shitori, Carbohydr. Res., 1987, 167, 77-86; (b) A. Hasegawa, T. Murase, M. Ogawa, H. Ishida and M. Kiso, J. Carbohydr. Chem., 1990, 9, 415.

8 A. Bianco, C. Melchioni, G. Ortaggi, P. Romagnoli and M. Brufani, J. Mol. Catal. B: Enzym., 1997, 3, 209. 